\title{
Soil Fertility, Phosphorus Fractions, and Maize Yield as Affected by Poultry Manure and Single Superphosphate
}

\author{
A. O. Ojo, ${ }^{1}$ M. T. Adetunji, ${ }^{2}$ K. A. Okeleye, ${ }^{2}$ and C. O. Adejuyigbe ${ }^{2}$ \\ ${ }^{1}$ Institute of Agricultural Research and Training, Obafemi Awolowo University, P.M.B 5029, Moor Plantation, \\ Ibadan, Oyo State, Nigeria \\ ${ }^{2}$ Federal University of Agriculture, Abeokuta, Nigeria
}

Correspondence should be addressed to A. O. Ojo; remia_ode@yahoo.com

Received 8 May 2014; Revised 13 August 2014; Accepted 19 August 2014

Academic Editor: Othmane Merah

Copyright (C) 2015 A. O. Ojo et al. This is an open access article distributed under the Creative Commons Attribution License, which permits unrestricted use, distribution, and reproduction in any medium, provided the original work is properly cited.

A field experiment was conducted in 2007 and 2008 on a slightly acidic alfisol. Poultry manure (PM) was applied at $0,5 \mathrm{tha}^{-1}$, $10 \mathrm{tha}^{-1}, 15 \mathrm{tha}^{-1}$, and $20 \mathrm{tha}^{-1}$ in combination with SSP at $0,15 \mathrm{~kg} \mathrm{Pha}^{-1}, 30 \mathrm{~kg} \mathrm{Pha}^{-1}, 45 \mathrm{~kg} \mathrm{Pha}^{-1}$, and $60 \mathrm{~kg} \mathrm{Pha}^{-1}$, which was replicated three times. The $\mathrm{pH}$ and organic $\mathrm{C}$ were significantly increased by the application of $\mathrm{PM}$ alone while available $\mathrm{P}$ was highly increased by the sole application of SSP. Plant tissue $\mathrm{P}$ was significantly increased with the application of $30 \mathrm{~kg} \mathrm{Pha}^{-1}$ while the largest grain yield was obtained when PM at $20 \mathrm{tha}^{-1}$ was combined with SSP at $60 \mathrm{~kg} \mathrm{P} \mathrm{ha}^{-1}$. The buildup of organic $\mathrm{P}$ was observed when $\mathrm{PM}$ was applied at $15 \mathrm{tha}^{-1}$ while the combination of the two treatments increased residual $\mathrm{P}$ and Fe-P. However, $\mathrm{P}$ occlusion was effectively reduced with the sole application of PM. Organic P and residual P however had a strong positive relationship with the grain yield. Comparing the sole and combined application of the treatments, the combined application was more effective for most of the parameters observed.

\section{Introduction}

Phosphorus $(\mathrm{P})$ is one of the essential elements for plant growth and the number of plants available $\mathrm{P}$ in the soil is often inadequate to meet plant requirements. Phosphorus is a macronutrient that plays a number of important roles in plant. Adequate phosphorus results in higher grain production, improved crop quality, greater stalk strength, increased root growth, and earlier crop maturity. Mokwunye et al. [1] and Warren [2] stated that phosphorus deficiency is one of the largest constraints to food production in tropical African soils due to low native $\mathrm{P}$ and high fixation by iron and aluminum oxides. It has also been established that phosphorus is relatively unavailable for plant uptake in highly weathered soils like the Ultisols [3]. In order to meet the need of phosphorus in these soils, farmers make use of inorganic fertilizers for their crops. However, P fertilizer is not readily available to these farmers because of scarcity in some cases and also due to the high cost of these fertilizers. Recently, farmers especially in the developed countries make use of organic manure which has been found to be effective like inorganic fertilizers for the release of some nutrients especially phosphorus but the resultant yield has been found not to be as high as when inorganic fertilizer is combined with the organic manure. Combining organic manure with $\mathrm{P}$ fertilizers has been found to not only increase yield but also reduce $\mathrm{P}$ fixation and subsequently increase phosphorus availability and uptake [3]. The study however aims at studying the effect of combined application of poultry manure and single superphosphate on phosphorus forms, soil fertility, and the yield maize.

\section{Materials and Methods}

The field experiment was conducted at I.A.R\&T experimental field at Ibadan in 2007 and 2008 early planting season (see Table 1). The experimental design was a $5 \times 5$ factorial experiment in a RCBD replicated three times. The plot size was $5 \mathrm{~m} \times 4 \mathrm{~m}\left(20 \mathrm{~m}^{2}\right)$ with spacing of $75 \mathrm{~cm} \times 50 \mathrm{~cm}$ to give a total plant population of 106,666 plants ha ${ }^{-1}$. Three seeds of maize (TZB-SR) were planted after 2 weeks of treatment incorporation. The seedlings were thinned to two per stand 
TABLE 1: Source of the soil used.

\begin{tabular}{lccccc}
\hline Location & State & Coordinates & Vegetation & Soil series & Soil class (USDA) \\
\hline Ibadan & Oyo & $\begin{array}{c}\text { Lat. } 7^{\circ} 30^{\prime} \\
\text { Long. } 3^{\circ} 54^{\prime}\end{array}$ & Rainforest & Iwo & Ferrudulf \\
\hline
\end{tabular}

TABLE 2: Sequential $\mathrm{P}$ fractionation procedures and targeted $\mathrm{P}$ forms.

\begin{tabular}{|c|c|c|c|c|}
\hline Location & Extractants & Equilibration & Washing & Targeted \\
\hline $\mathrm{NH}_{4} \mathrm{Cl}-\mathrm{P}$ & $\mathrm{IM} \mathrm{NH}_{4} \mathrm{Cl}$ & 30 mins & None & $\begin{array}{l}\text { Saloid-bound P } \\
\text { (loosely bound P) }\end{array}$ \\
\hline $\mathrm{NH}_{4} \mathrm{~F}-\mathrm{P}$ & $0.5 \mathrm{M} \mathrm{NH}_{4} \mathrm{~F}$ & 1 hour & None & Al-P \\
\hline $\mathrm{NaOH}-\mathrm{P}$ & $\begin{array}{c}0.1 \mathrm{M} \mathrm{NaOH} \text { saturated } \\
\mathrm{Nacl}+5 \text { drops of conc. } \mathrm{H}_{2} \mathrm{SO}_{4}\end{array}$ & 15 mins & Saturated Nacl & Fe-P \\
\hline $\begin{array}{l}\text { Sodium + citrate } \\
\text { Sodium dithionite } \mathrm{P}\end{array}$ & $\begin{array}{l}0.3 \mathrm{M} \text { sodium citrate }+1 \mathrm{~g} \text { solid } \\
\text { Sodium dithionate }+ \text { sat } \mathrm{Nacl}\end{array}$ & $\begin{array}{l}\text { Shake } 15 \text { mins, preheat } 15 \text { mins at } \\
85^{\circ} \mathrm{C} \text { after sodium citrate, } \\
\text { additional } 15 \text { mins after } \\
\text { dithionite addition }\end{array}$ & Saturated Nacl & Reductant-soluble P \\
\hline $\mathrm{NaOH}-\mathrm{P}$ & $\begin{array}{c}0.1 \mathrm{M} \mathrm{NaOH}+\text { few drops of conc. } \\
\mathrm{H}_{2} \mathrm{SO}_{4} \text { to remove colour }\end{array}$ & $15 \mathrm{mins}$ & Saturated $\mathrm{NaCl}$ & Occluded P \\
\hline $\mathrm{H}_{2} \mathrm{SO}_{4}-\mathrm{P}$ & $0.25 \mathrm{M} \mathrm{H}_{2} \mathrm{SO}_{4}+25 \mathrm{~mL}$ Sat. Nacl & 1 hour & Saturated Nacl & $\mathrm{Ca}-\mathrm{P}$ \\
\hline Residual P & Conc. $\mathrm{HNO}_{3}+\mathrm{HCl}+30 \% \mathrm{H}_{2} \mathrm{O}_{2}$ & Variable until complete & None & $\begin{array}{c}\text { Organically stable } \\
\text { organic and inorganic } \mathrm{P}\end{array}$ \\
\hline
\end{tabular}

two weeks after planting. The plots were not tilled in the early season (May) for the second year (2008) in order to avoid mixing up of treatments. Gramoxone and primextra were used as herbicides. Weeding was done at the 4 th and 8 th week after planting.

Leaf sampling of maize was done at eight weeks after planting. Leaf just below and opposite the ear was sampled randomly per plot. Ears of maize were allowed to dry on the stalk. Ears in the four middle rows of each plot were harvested (making allowance for two guard rows) on each side of the plot. The cobs were dehusked and weighed. Ten cobs per plots were randomly selected for cob weight measurement. The cobs were sun dried and the grains were weighed. Yield per hectare was computed at $12 \%$ moisture content for maize. Soil samples were analyzed before and after for phosphorus fractions and soil nutrient composition.

2.1. Soil Physical and Chemical Analysis. Particle size distribution was determined by the hydrometer method [4] using sodium hexametaphosphate as the dispersing agent. Soil $\mathrm{pH}$ was determined in distilled water (1:1 soil water ratio) with a $\mathrm{pH}$ meter. Exchangeable cations ( $\mathrm{K}, \mathrm{Na}, \mathrm{Ca}$, and $\mathrm{Mg}$ ) by extraction, with ammonium acetate $(\mathrm{pH}=7)$. Available $\mathrm{P}$ was extracted with $0.03 \mathrm{~N} \mathrm{NH}_{4} \mathrm{~F}$ in $0.025 \mathrm{~N} \mathrm{HCl}$ solution [5] and $\mathrm{P}$ in the extract was analysed colorimetrically by the molybdenum blue method at $660 \mathrm{~nm}$. Soil organic carbon was determined by wet oxidation with sulphuric acid [6]. Total $\mathrm{P}$ was determined by wet digestion using perchloric acid and nitric acid while organic $\mathrm{P}$ was by ignition method. Phosphorus concentration in the digests was determined using the ascorbic acid method.
2.2. Phosphorus Fractionation Study. Fractionation procedure by Chang and Jackson [7] was used to quantify different forms of inorganic $\mathrm{P}$ in the studied soils (Table 2). Fractionation was done on the soil before and after amendment for incubation, greenhouse, and field experiment. The sequence of the chemical extraction and a brief description of the targeted $\mathrm{P}$ forms are shown in Table 2.

2.3. Determination of Phosphorus in the Extracts. The phosphorus in the extracts was determined by the methyl blue colour method of Murphy and Riley [8]. An aliquot of $10 \mathrm{~mL}$ was used in developing the colour. The determination of $\mathrm{P}$ in $\mathrm{NH}_{4} \mathrm{~F}, \mathrm{NaOH}$, and $\mathrm{DCB}$ extracts however requires the following pretreatment before the development of the colour.

(a) $\mathrm{NH}_{4} \mathrm{~F}$ extract: $0.05 \mathrm{~g}$ of $\mathrm{H}_{3} \mathrm{BO}_{3}$ per $50 \mathrm{~mL}$ of the extract was added before taking the aliquot.

(b) $\mathrm{NaOH}$ extract: after precipitating the organic matter with conc. $\mathrm{H}_{2} \mathrm{SO}_{4}$, the $\mathrm{pH}$ of the extract was adjusted with $\mathrm{NaOH}$ using 2,4-dinitrophenol indicator. An aliquot of the clear solution was then taken into a $50 \mathrm{~mL}$ volumetric flask.

(c) DCB extract (reductant soluble P): $10 \mathrm{~mL}$ of the extract was pipetted into a test tube and $1 \mathrm{~mL}$ of $\mathrm{HClO}_{4}$ was added to it and boiled to destroy the dithionite in the extract. It was then transferred into a $50 \mathrm{~mL}$ volumetric flask and $3 \mathrm{~mL}$ of $5 \%$ ammonium molybdate solution was added while distilled water was used to make up to mark. Absorbance was read after 30 minutes. 
TABLE 3: Chemical and physical properties of the soil used for the study.

\begin{tabular}{lc}
\hline Parameters & \\
\hline $\mathrm{pH}\left(\mathrm{H}_{2} \mathrm{O}\right)$ & 6.4 \\
$\mathrm{O} . \mathrm{M}\left(\mathrm{g} \mathrm{kg}^{-1}\right)$ & 24.08 \\
$\mathrm{~N}\left(\mathrm{~g} \mathrm{~kg}^{-1}\right)$ & 0.2 \\
$\mathrm{P}\left(\mathrm{mg} \mathrm{kg}^{-1}\right)$ & 14.2 \\
Exchangeable cations $\left(\mathrm{c} \mathrm{molc} \mathrm{kg}^{-1}\right)$ & \\
$\quad \mathrm{Ca}$ & 1.14 \\
$\quad \mathrm{Mg}$ & 0.82 \\
$\mathrm{~K}$ & 0.47 \\
$\quad \mathrm{Na}$ & 0.09 \\
Particle size $\left(\mathrm{g} \mathrm{kg}^{-1}\right)$ & \\
$\quad$ Sand & 740 \\
$\quad$ Clay & 120 \\
$\quad$ Silt & 140 \\
\hline
\end{tabular}

2.4. Analysis of Poultry Manure Sample. Total analysis of the sample was done by weighing $0.5 \mathrm{~g}$ of poultry manure, adding $10 \mathrm{~mL}$ of $\mathrm{HNO}_{3} / \mathrm{HClO}_{4},(2: 1)$, and digesting at $150^{\circ} \mathrm{C}$. The temperature was increased at 1.5 hours to $230^{\circ} \mathrm{C}$ and $2 \mathrm{~mL}$ of $\mathrm{HCl} / \mathrm{H}_{2} \mathrm{O}(1: 1)$ was added. The digestion was now continued for another 30 minutes [9].

2.5. Statistical Analysis. The data collected were subjected to analysis of variance using the statistical analysis system (SAS)-general linear model [10]. Means were separated by Duncan multiple range test.

\section{Results}

3.1. Initial Chemical Properties of the Soil Used. The $\mathrm{pH}$ of the soil was slightly acidic and therefore a need for the application of organic manure. The soil was low in $\mathrm{N}, \mathrm{Na}$, and organic carbon while $\mathrm{P}$ was moderately available in it. It was however adequate with cations like $\mathrm{Ca}, \mathrm{Mg}$, and $\mathrm{K}$ (Table 3).

\subsection{Characterization of the Poultry Manure Used and the} Initial Phosphorus Fractions of the Soil. Nitrogen in the poultry manure used was $5.82 \%$ which was similar to the result observed for phosphorus (5.54\%) while potassium was low in the soil $(0.94 \%)$. Organic $\mathrm{C}$ had a high percentage of $13.38 \%$ which led to the resultant $\mathrm{C} / \mathrm{N}$ ratio of 2.3 (Table 4 ). Also notable was the result obtained for Fe $(1555 \mathrm{mg} / \mathrm{kg})$.

The order of abundance of the phosphorus fractions before the application of treatments was organic $\mathrm{P}>\mathrm{Fe}-\mathrm{P} \equiv$ occluded $\mathrm{P}>$ residual $\mathrm{P}$ (Table 5).

3.3. Effect of Combined Application of Poultry Manure and SSP on the Soil Chemical Properties. There was a decrease in $\mathrm{pH}$ as a result of the sole application of SSP in 2007, which further decreased in 2008 (Table 6). Application of poultry manure alone increased the $\mathrm{pH}$ of the soil significantly when compared to the other treatments. However, the combined application of poultry manure and SSP increased the $\mathrm{pH}$ of
TABLE 4: Characterization of the poultry manure used.

\begin{tabular}{lc}
\hline $\mathrm{pH}$ & 7.03 \\
Nitrogen (N) (\%) & 5.82 \\
Phosphorus (P) (\%) & 5.54 \\
Potassium (K) (\%) & 0.94 \\
$\mathrm{Na}(\%)$ & 1.3 \\
$\mathrm{SO}_{4}-\mathrm{S}(\%)$ & 0.14 \\
Organic C (\%) & 13.34 \\
$\mathrm{C} / \mathrm{N}$ & 2.3 \\
Calcium $(\%)$ & 8.04 \\
Magnesium (\%) & 0.61 \\
Iron (mg kg & 1555 \\
Copper $\left(\mathrm{mg} \mathrm{kg}^{-1}\right)$ & 33.3 \\
Zinc (mg kg-1) & 100.3 \\
Manganese $\left(\mathrm{mg} \mathrm{kg}^{-1}\right)$ & 180 \\
\hline
\end{tabular}

TABLE 5: Phosphorus fractions of the soil before planting $\left(\mathrm{mg} \mathrm{kg}^{-1}\right)$.

\begin{tabular}{lc}
\hline Phosphorus fractions $\left(\mathrm{mg} \mathrm{kg}^{-1}\right)$ & 272.84 \\
\hline Total P & 45.90 \\
Organic P & 33.39 \\
Fe-P & 33.39 \\
Occluded P & 16.16 \\
\hline
\end{tabular}

the soil in 2007 with a further increase in 2008. In other words, poultry manure alone can be compared favorably with the combined application of poultry manure and SSP in increasing soil $\mathrm{pH}$ especially in slightly acidic soil. Effect of SSP on organic C was not significant and decreased when compared to the initial value. However, the application of poultry manure increased organic $\mathrm{C}$ significantly when poultry manure was applied alone in 2007. In 2008, organic C further increased with the sole application of poultry manure. The effect of the combined application of poultry manure and SSP was not significant on organic carbon in 2007 but significant in 2008 with the combined application of poultry manure and SSP. Available P increased over the control either with the sole application of poultry manure or SSP or when the two treatments were combined. However, in 2007 the sole application of SSP was more effective in increasing available $\mathrm{P}$ than the sole application of poultry manure but was the most effective with the combined application of poultry manure and SSP, while, in 2008, the combined treatments were not significant but the sole application was.

3.4. Effect of the Combined Application of Poultry Manure and SSP on Plant Tissue P Concentration and Grain Yield of Maize. Effect of poultry manure and SSP alone with their combinations was significant in both years (Table 7). In 2007, plant tissue $\mathrm{P}$ was high when the treatments were applied solely but combined application was highly significant. Plant tissue $\mathrm{P}$ continued to increase in 2008 with the sole and combined application but with the most significant increase with the sole application of SSP. 
TABLE 6: Effect of poultry manure (PM) and SSP on some soil chemical properties in 2007 and 2008.

\begin{tabular}{|c|c|c|c|c|c|c|c|}
\hline \multicolumn{2}{|c|}{ Treatments } & \multirow{2}{*}{$\mathrm{pH}(2007)$} & \multirow{2}{*}{ pH (2008) } & \multirow{2}{*}{$\begin{array}{c}\text { Organic C, } \\
\%(2007)\end{array}$} & \multirow{2}{*}{$\begin{array}{c}\text { Organic C, } \\
\%(2008)\end{array}$} & \multirow{2}{*}{$\begin{array}{l}\text { Available } \mathrm{P}, \\
\mathrm{mg} \mathrm{kg}^{-1}(2007)\end{array}$} & \multirow{2}{*}{$\begin{array}{l}\text { Available P, } \\
\mathrm{mg} \mathrm{kg}^{-1} \text { (2008) }\end{array}$} \\
\hline $\mathrm{PM}\left(\mathrm{tha}^{-1}\right)$ & $\operatorname{SSP}\left(\mathrm{kg} \mathrm{Pha}^{-1}\right)$ & & & & & & \\
\hline \multirow{5}{*}{0} & 0 & 6.23 & 6.30 & 0.19 & 0.16 & 5.90 & 6.07 \\
\hline & 15 & 6.73 & 6.73 & 0.62 & 0.85 & 92.57 & 96.78 \\
\hline & 30 & 6.32 & 6.30 & 1.02 & 1.27 & 39.41 & 39.91 \\
\hline & 45 & 6.51 & 6.51 & 1.26 & 0.74 & 69.60 & 70.02 \\
\hline & 60 & 6.42 & 6.87 & 0.75 & 0.89 & 42.56 & 41.18 \\
\hline \multirow{5}{*}{5} & 0 & 7.06 & 7.06 & 0.65 & 1.05 & 41.50 & 41.70 \\
\hline & 15 & 6.53 & 6.53 & 0.92 & 1.90 & 56.39 & 56.27 \\
\hline & 30 & 6.52 & 6.52 & 1.06 & 1.42 & 43.56 & 43.84 \\
\hline & 45 & 6.65 & 6.62 & 1.12 & 1.29 & 90.05 & 87.66 \\
\hline & 60 & 6.92 & 6.92 & 0.91 & 0.97 & 64.69 & 65.82 \\
\hline \multirow{5}{*}{10} & 0 & 6.87 & 6.87 & 1.03 & 1.39 & 64.82 & 63.30 \\
\hline & 15 & 6.82 & 6.73 & 1.03 & 1.04 & 59.62 & 59.74 \\
\hline & 30 & 6.72 & 6.72 & 1.37 & 0.87 & 67.06 & 66.74 \\
\hline & 45 & 6.86 & 6.86 & 0.98 & 1.34 & 83.32 & 81.65 \\
\hline & 60 & 6.87 & 6.87 & 1.02 & 1.53 & 60.42 & 60.42 \\
\hline \multirow{5}{*}{15} & 0 & 6.50 & 6.50 & 1.63 & 1.52 & 40.05 & 96.78 \\
\hline & 15 & 6.87 & 6.93 & 1.66 & 2.65 & 67.71 & 67.78 \\
\hline & 30 & 6.80 & 6.80 & 1.08 & 1.45 & 96.82 & 87.49 \\
\hline & 45 & 6.65 & 6.72 & 1.08 & 1.62 & 88.31 & 87.24 \\
\hline & 60 & 6.62 & 7.16 & 1.25 & 1.50 & 75.57 & 74.54 \\
\hline \multirow{9}{*}{20} & 0 & 6.93 & 6.93 & 1.03 & 1.75 & 59.60 & 53.07 \\
\hline & 15 & 6.60 & 6.60 & 0.78 & 1.01 & 72.68 & 76.81 \\
\hline & 30 & 6.60 & 6.60 & 1.22 & 1.26 & 72.68 & 79.69 \\
\hline & 45 & 6.50 & 6.50 & 0.82 & 1.12 & 64.87 & 64.44 \\
\hline & 60 & 6.97 & 6.96 & 1.23 & 2.60 & 61.74 & 94.84 \\
\hline & $\operatorname{LSD}(P \leq 0.05)$ & & & & & & \\
\hline & SSP & $*$ & $*$ & NS & * & * & NS \\
\hline & $\mathrm{PM}$ & $*$ & $*$ & $*$ & * & $*$ & NS \\
\hline & $\mathrm{SSP} \times \mathrm{PM}$ & * & NS & NS & $*$ & $*$ & NS \\
\hline
\end{tabular}

${ }^{*}$ Significant at $P<0.05$, NS: not significant.

The sole application of SSP had no significant effect on the grain yield of maize in 2007 while the sole application of poultry manure and the combined application of the two treatments were significant in the same year. However, in 2007 , the highest grain yield of maize was obtained by the sole application of poultry manure. In 2008, effect of the sole application of poultry manure and SSP on maize grain yield was significant while the combined application was not. The combined application of the two treatments gave the highest grain yield in 2008 .

3.5. Effect of the Combined Application of Poultry Manure and SSP on Phosphorus Fractions. Effect of the sole and combined application of poultry manure and SSP was significant in both 2007 and 2008 (Table 8). In 2007, organic P was significantly increased over the initial value when poultry manure was applied solely than when SSP was applied alone. Combining the two treatments also increased organic P significantly in 2007. The application of poultry manure alone however gave the highest increase in organic P in 2007. In 2008, organic P reduced with the sole application of SSP but increased when poultry manure was applied alone and with some combined treatments. The sole application of poultry manure was again effective in 2008 in increasing organic P. Residual P increased over the control when poultry manure and SSP were applied alone and when combined in both years. Residual $P$ increased in 2007 with the combined application of the two treatments but reduced in 2008. A similar trend to that of residual P was observed for Fe-P but with few exceptions when the 2 treatments were combined. In 2008, the largest buildup of Fe-P was observed with the combined application of poultry manure and SSP. In both years of cropping, sole application of poultry manure was effective in reducing $\mathrm{P}$ occlusion more than the combined application. 
TABLE 7: Effect of poultry manure (PM) and SSP on plant tissue concentration and grain yield in 2007 and 2008.

\begin{tabular}{|c|c|c|c|c|c|}
\hline \multicolumn{2}{|c|}{ Treatments } & \multicolumn{2}{|c|}{ Plant tissue (\%) $\mathrm{P}$} & \multicolumn{2}{|c|}{ Grain yield $\left(\mathrm{tha}^{-1}\right)$} \\
\hline $\mathrm{PM}\left(\mathrm{tha}^{-1}\right)$ & $\operatorname{SSP}\left(\mathrm{kg} \mathrm{Pha}^{-1}\right)$ & 2007 & 2008 & 2007 & 2008 \\
\hline \multirow{5}{*}{0} & 0 & 0.43 & 0.53 & 1.33 & 0.81 \\
\hline & 15 & 0.94 & 1.04 & 3.12 & 3.21 \\
\hline & 30 & 0.82 & 2.51 & 2.29 & 1.45 \\
\hline & 45 & 1.29 & 2.02 & 2.57 & 1.05 \\
\hline & 60 & 0.79 & 1.93 & 2.39 & 1.42 \\
\hline \multirow{5}{*}{5} & 0 & 0.88 & 0.77 & 2.76 & 1.98 \\
\hline & 15 & 1.97 & 1.56 & 2.61 & 1.25 \\
\hline & 30 & 0.87 & 0.96 & 2.69 & 1.67 \\
\hline & 45 & 0.85 & 2.50 & 2.71 & 1.74 \\
\hline & 60 & 0.82 & 1.24 & 2.35 & 2.57 \\
\hline \multirow{5}{*}{10} & 0 & 1.32 & 0.86 & 2.87 & 1.66 \\
\hline & 15 & 1.49 & 1.82 & 2.46 & 2.18 \\
\hline & 30 & 1.01 & 1.33 & 2.59 & 3.02 \\
\hline & 45 & 1.61 & 0.84 & 2.48 & 1.78 \\
\hline & 60 & 1.28 & 1.35 & 2.42 & 3.53 \\
\hline \multirow{5}{*}{15} & 0 & 2.00 & 1.04 & 3.63 & 0.83 \\
\hline & 15 & 1.82 & 1.01 & 2.75 & 3.85 \\
\hline & 30 & 0.87 & 0.83 & 2.75 & 3.50 \\
\hline & 45 & 1.49 & 1.42 & 2.60 & 3.21 \\
\hline & 60 & 0.93 & 1.02 & 2.20 & 3.76 \\
\hline \multirow{9}{*}{20} & 0 & 1.03 & 0.94 & 2.82 & 2.82 \\
\hline & 15 & 0.87 & 1.36 & 2.86 & 2.41 \\
\hline & 30 & 1.36 & 1.52 & 2.64 & 2.44 \\
\hline & 45 & 0.99 & 2.09 & 2.36 & 2.30 \\
\hline & 60 & 0.99 & 1.35 & 2.37 & 3.99 \\
\hline & $\operatorname{LSD}(P \leq 0.05)$ & & & & \\
\hline & SSP & * & * & NS & * \\
\hline & PM & * & $*$ & * & * \\
\hline & $\mathrm{SSP} \times \mathrm{PM}$ & * & * & * & NS \\
\hline
\end{tabular}

* Significant at $P<0.05$, NS: not significant.

3.6. Relationship among the P Fractions, Soil Chemical Properties, and Maize Grain Yield. In 2007, the $\mathrm{pH}$ of the soil had a strong negative relationship with Al-P and occluded $\mathrm{P}$ but positive relationship with residual $\mathrm{P}$ (Table 9), while in 2008 , increase in the $\mathrm{pH}$ of the soil favored the buildup of FeP (Table 10). Available P in 2007 had a positive correlation with organic $\mathrm{P}, \mathrm{Ca}-\mathrm{P}$, and $\mathrm{Fe}-\mathrm{P}$ but a negative correlation with occluded P. Organic C had no significant relationship with the $\mathrm{P}$ fractions in 2007 but a positive correlation with organic $\mathrm{P}$ and a negative correlation with occluded $\mathrm{P}$ in 2008. Organic $\mathrm{P}$ and residual $\mathrm{P}$ contributed positively to the maize grain yield in both 2007 and 2008.

\section{Discussion}

4.1. Initial Chemical Properties of the Soil Used. The $\mathrm{pH}$ of the soil was slightly acidic and this will make Fe-P be more available than the other inorganic P fractions. Although phosphorus was moderately available, poultry manure and SSP were further applied in order to study the effect of continuous application of organic and inorganic fertilizer on such soils yearly as has been practiced by many farmers in Nigeria.

4.2. Characterization of the Poultry Manure Used and Initial Phosphorus Fractions of the Soil. A common and traditional practice has utilized manure as an organic fertilizer or soil improver due to its contribution of organic matter and nutrients, mainly $\mathrm{N}$ and $\mathrm{P}$ [11]. The high percentage of nitrogen in the poultry manure used could have been due to the decomposition of poultry manure during the curing stage before application to the soil with a subsequent release of $\mathrm{N}$ which was detected during the analysis. Manure in past studies has been applied according to the nitrogen needs of the soil [12]. Macronutrients such as phosphorus are part of the advantage of using organic waste in agriculture, which may be recovered and incorporated into natural cycle and this was evident in the percentage of phosphorus in the poultry manure used. It also contains a high level of organic matter 


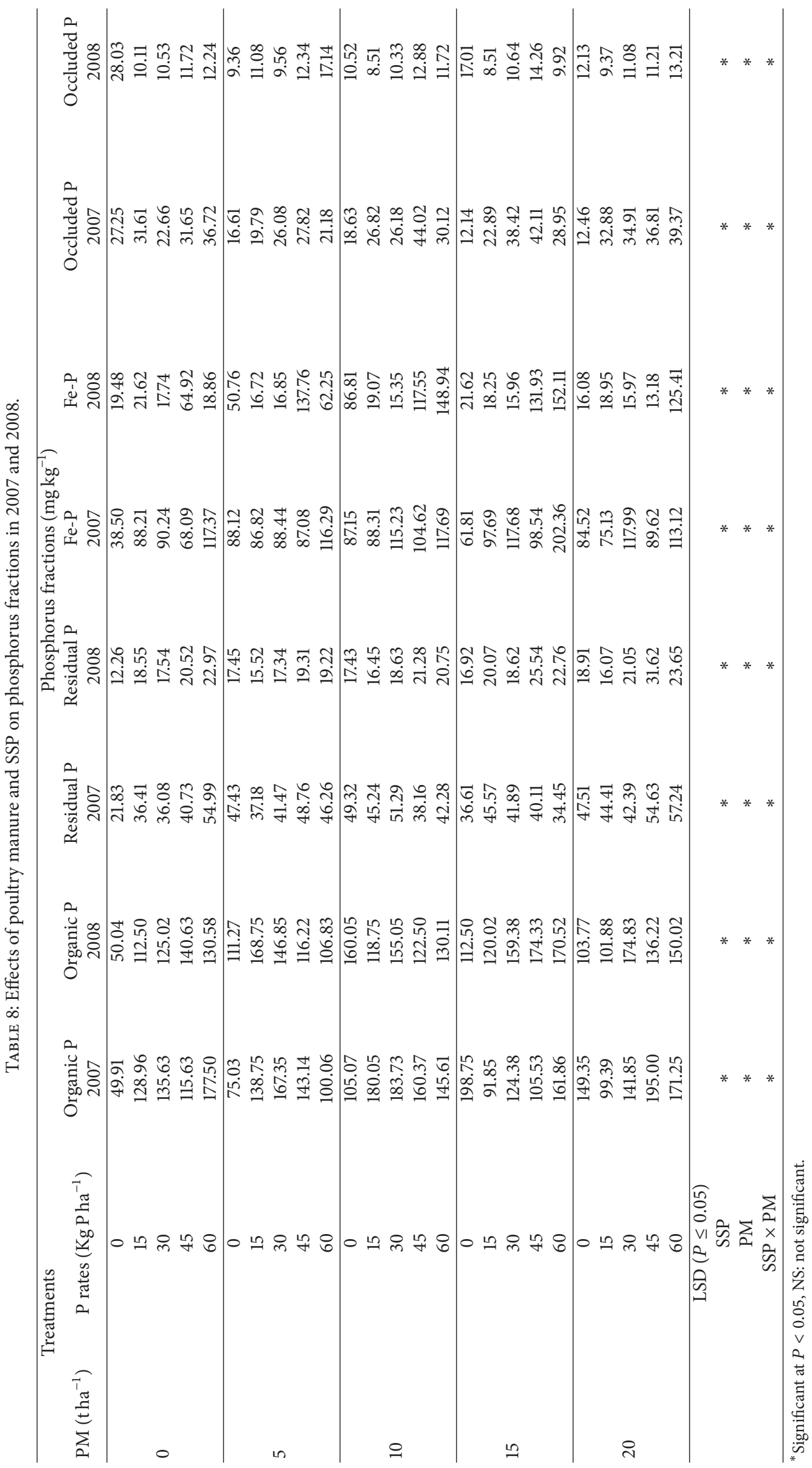


TABLE 9: Correlation coefficient $(r)$ among $P$ fractions, soil chemical properties, and maize grain yield in 2007.

\begin{tabular}{lcccc}
\hline \multirow{2}{*}{ Soil properties } & \multicolumn{3}{c}{ P fractions $\left(\mathrm{mg} \mathrm{kg}^{-1}\right)$} \\
& Organic P & Fe-P & Occluded P & Residual P \\
\hline pH & 0.098 & 0.201 & -0.550 & 0.633 \\
Available P & 0.514 & 0.433 & -0.528 & -0.071 \\
Organic C & 0.206 & 0.115 & -0.031 & -0.105 \\
Grain yield & 0.413 & 0.145 & 0.034 & 0.402 \\
\hline
\end{tabular}

TABLE 10: Correlation coefficient $(r)$ among P fractions, soil chemical properties, and maize grain yield in 2008 .

\begin{tabular}{lcccc}
\hline \multirow{2}{*}{ Soil properties } & \multicolumn{3}{c}{ P fractions $\left(\mathrm{mg} \mathrm{kg}^{-1}\right)$} \\
& Organic P & Fe-P & Occluded P & Residual P \\
\hline $\mathrm{pH}$ & 0.118 & 0.458 & 0.065 & -0.144 \\
Available P & 0.053 & 0.173 & -0.753 & 0.048 \\
Organic C & 0.500 & 0.122 & -0.557 & -0.177 \\
Grain yield & 0.403 & 0.105 & 0.123 & 0.412 \\
\hline
\end{tabular}

which generates changes in chemical, physical, and biological soil amendment properties [12].

Organic $\mathrm{P}$ was the highest $\mathrm{P}$ fraction at the initial stage of this study. About two-thirds of the phosphorus in fresh manure is in organic form [12]. The organic P pool is usually considered a major source of organic phosphorus and can be converted to inorganic $\mathrm{P}$ by ignition or wet digestion. Initial abundance of Fe-P could be attributed to the acidic nature of the soil; however occluded $\mathrm{P}$ also had the same value which could mean there is an equilibrium reaction between the labile and the nonlabile $\mathrm{P}$ fractions.

4.3. Effect of Combined Application of Poultry Manure and SSP on the Soil Chemical Properties. Acidity in sols if not properly managed will eventually make the soil be low or not yielding and therefore a need for amendment. In this study, application of poultry manure compared favourably with the combined application of poultry manure and SSP in increasing the $\mathrm{pH}$ of the soil while applying inorganic fertilizer alone decreased the soil $\mathrm{pH}$. Soil $\mathrm{pH}$ of an acidic Ultisol in the eastern Nigeria was observed to increase soil pH [13]. Sole and combined organic and inorganic fertilizer has been found to increase soil nutrients favorably. The combined application of the two treatments was highly effective in increasing soil organic C in both 2007 and 2008. Earlier studies on poultry manure ability to increase soil organic C have been reported $[13,14]$, likewise when it is combined with SSP [15]. Single superphosphate was however more effective than the sole application of poultry manure for increasing the available $\mathrm{P}$ content of the soil although the combined application of the two treatments still gave the highest value [16]. The effectiveness of SSP for available P over poultry manure could be due to the immediate release of phosphate into the soil when SSP is being applied. and SSP on Plant Tissue P Concentration and Grain Yield of
Maize. High plant tissue P was obtained in 2007 and 2008 with the sole and combined application of poultry manure and SSP. However, the sole application of SSP was however sustainable in the 2nd year to cause a further increase in the concentration of $\mathrm{P}$ in the shoot. A similar result has been observed by Adeniyan and Ojeniyi, [17]. The increase in the plant tissue $\mathrm{P}$ in 2008 was as a result of $\mathrm{P}$ accumulation observed in both years, which would have resulted in the transfer to the shoot of the plant instead of being washed into nearby river and hereby preventing eutrophication.

When the treatments were applied solely, application of poultry manure alone was more effective than SSP, that is, considering the high grain yield. Although this was in the first year of planting, the combined application of poultry manure and SSP was again sustainable in the second year. The combined application of organic and inorganic resources has been found to favor maize production [14].

4.5. Effect of the Combined Application of Poultry Manure and SSP on Phosphorus Fractions. The buildup of organic P was observed in both years of this study with the sole application of poultry manure and this signifies the importance of organic manure when considering amendments for an acidic soil. Addition of soybean residue and wheat residue or in combination with fertilizer $P$ favored the buildup of organic $\mathrm{P}$ in a study [18]. The inorganic $\mathrm{P}$ fractions considered, that is, residual $\mathrm{P}$ and $\mathrm{Fe}-\mathrm{P}$, was significantly increased when poultry manure was combined with SSP. This indicates the ability of the combined application of poultry manure and SSP to maintain the fertility of the soil through increase in the labile P fraction [19]. Residual P however reduced in 2008 and this was also observed by Agbenin and Goladi, [20] in an experiment involving the addition of $P$ fertilizers or in combination with cow manure. Significant was the ability of poultry manure alone to reduce $\mathrm{P}$ occlusion in both years, that is, occluded $\mathrm{P}$, which further confirms an earlier study which states that addition of organic materials to soil decreases $\mathrm{P}$ fixation [3]. Inorganic and organic products are generated during the partial decomposition of organic waste and organic acids can be adsorbed into the soil surface thereby decreasing the potential $\mathrm{P}$ adsorption by blocking the formation of complexes [21].

4.6. Relationship among the P Fractions, Soil Chemical Properties, and Maize Grain Yield. Organic P and Fe-P contributed significantly to the increase observed in available P in 2007 while occluded $\mathrm{P}$ decreased with an increase in available P. This further confirms the importance of poultry manure while considering soil amelioration. In both years of cropping, organic $\mathrm{P}$ was sustainable in increasing grain yield but Fe-P was only effective in 2007. Residual P (a nonlabile $\mathrm{P}$ fraction) equally contributed to the increase observed in grain yield in both years. In other words, there would have been an equilibrium reaction between the nonlabile $\mathrm{P}$ (residual P) and labile P (Fe-P) fraction which would have subsequently resulted in an increase in available $P$. 


\section{Conclusion}

Application of poultry manure alone was effective in increasing the $\mathrm{pH}$, organic $\mathrm{C}$, and available $\mathrm{P}$ content of the soil. However, application of SSP was highly significant in increasing the available $\mathrm{P}$ content of the soil and this was evident in the increase obtained for the plant tissue P in 2008, while, for grain yield, the most effective was the combined application of poultry manure and SSP. Increase in organic $\mathrm{P}$ fraction was as a result of the application of poultry manure while the combined application of poultry manure and SSP increased the Fe-P fraction. Poultry manure alone was also the most effective treatment for the reduction of $\mathrm{P}$ occlusion in the soil. Significant were also the importance of poultry manure and the combined application of poultry manure and SSP exhibited through the strong relationship that existed among available $\mathrm{P}, \mathrm{Fe}-\mathrm{P}$, and organic $\mathrm{P}$. Although poultry manure was compared favorably with the combined application of poultry manure and SSP, the combination of the treatments was more suitable for the sustainability of the fertility of the slightly acidic soil.

\section{Conflict of Interests}

The authors declare that there is no conflict of interests regarding the publication of this paper.

\section{References}

[1] A. U. Mokwunye, S. H. Chien, and E. Rhodes, "Phosphorus reaction with tropical African soils," in Management of Nitrogen and Phosphorus Fertilizers in Sub-Saharan African, A. U. Mokwanye and P. L. C. Vick, Eds., pp. 253-281, Martins Nulhoff, Dordrecht, The Netherlands, 1986.

[2] G. Warren, Fertilizer Phosphorus Sorption and Residual Value in Tropical African Soils, NRI Bulletin 37, Natural Resource Institute, Chatham, UK, 1992.

[3] F. Iyamuremye, R. P. Dick, and J. Baham, "Organic amendments and phosphorus dynamics: I. Phosphorus chemistry and sorption," Soil Science, vol. 161, no. 7, pp. 426-435, 1996.

[4] G. J. Bouyoucos, "Hydrometer method improved for making particle size analysis of soils," Agronomy Journal, vol. 54, no. 5, pp. 464-465, 1962.

[5] R. H. Bray and L. T. Kurtz, "Determination of total, organic and available forms of phosphorus in soils," Soil Science, vol. 59, pp. 39-45, 1945.

[6] A. Walkey and I. A. Black, "An examination of the Degtjareff method for determining organic carbon in soils: effect of variations in digestion conditions and of inorganic soil constituents," Soil Science, vol. 63, pp. 251-263, 1934.

[7] S. C. Chang and M. L. Jackson, "Fraction of soil phosphates," Soil Science, vol. 83, pp. 133-144, 1957.

[8] J. Murphy and J. P. Riley, "A modified single solution method for the determination of phosphate in natural waters," Analytica Chimica Acta, vol. 27, pp. 31-36, 1962.

[9] E. J. Udo and J. A. Ogunwale, Manual of Soil, Plant and Water Analysis, Department of Agronomy, University of Ibadan, Ibadan, Nigeria, 1978.

[10] SAS Institute, SAS for Linear Models. A Guide to the ANOVA and GLM Procedures, SAS Institute, Cary, NC, USA, 2000.
[11] Z. He, T. S. Griffin, and C. W. Honeycutt, "Evaluation of soil phosphorus transformations by sequential fractionation and phosphatase hydrolysis," Soil Science, vol. 169, no. 7, pp. 515-527, 2004.

[12] B. J. Wienhold, "Changes in soil attributes following low phosphorus swine slurry application to no-tillage sorghum," Soil Science Society of America Journal, vol. 69, no. 1, pp. 206214, 2005.

[13] A. O. Ano and J. A. Agwu, "Effects of animal manures on selected soil chemical properties," Nigeria Journal of Soil Science, vol. 15, pp. 14-19, 2005.

[14] L. R. Bulluck III, M. Brosius, G. K. Evanylo, and J. B. Ristaino, "Organic and synthetic fertility amendments influence soil microbial, physical and chemical properties on organic and conventional farms," Applied Soil Ecology, vol. 19, no. 2, pp. 147$160,2002$.

[15] M. C. Manna, A. Swarup, R. H. Wanjari, B. Mishra, and D. K. Shahi, "Long-term fertilization, manure and liming effects on soil organic matter and crop yields," Soil and Tillage Research, vol. 94, no. 2, pp. 397-409, 2007.

[16] H. Zhang, B. Wang, and M. Xu, "Effects of inorganic fertilizer inputs on grain yields and soil properties in a long-term wheatcorn cropping system in South China," Communications in Soil Science and Plant Analysis, vol. 39, no. 11-12, pp. 1583-1599, 2008.

[17] O. N. Adeniyan and S. O. Ojeniyi, "Effect of poultry manure, NPK 15-15-15 and combination of their reduced levels on growth and soil chemical properties," Nigeria Journal of Soil Science, vol. 15, pp. 34-41, 2005.

[18] D. D. Reddy, S. A. Rao, and M. Singh, "Changes in P fractions and sorption in an Alfisol following crop residues application," Journal of Plant Nutrition and Soil Science, vol. 168, no. 2, pp. 241-247, 2005.

[19] T. Q. Zhang and A. F. MacKenzie, "Changes of soil phosphorous fractions under long-term corn monoculture," Soil Science Society of America Journal, vol. 61, no. 2, pp. 485-493, 1997.

[20] J. O. Agbenin and J. T. Goladi, "Dynamics of phosphorus fractions in a savanna Alfisol under continuous cultivation," Soil Use and Management, vol. 14, no. 2, pp. 59-64, 1998.

[21] M. S. Mkhabela and P. R. Warman, "The influence of municipal solid waste compost on yield, soil phosphorus availability and uptake by two vegetable crops grown in a Pugwash sandy loam soil in Nova Scotia," Agriculture, Ecosystems and Environment, vol. 106, no. 1, pp. 57-67, 2005. 

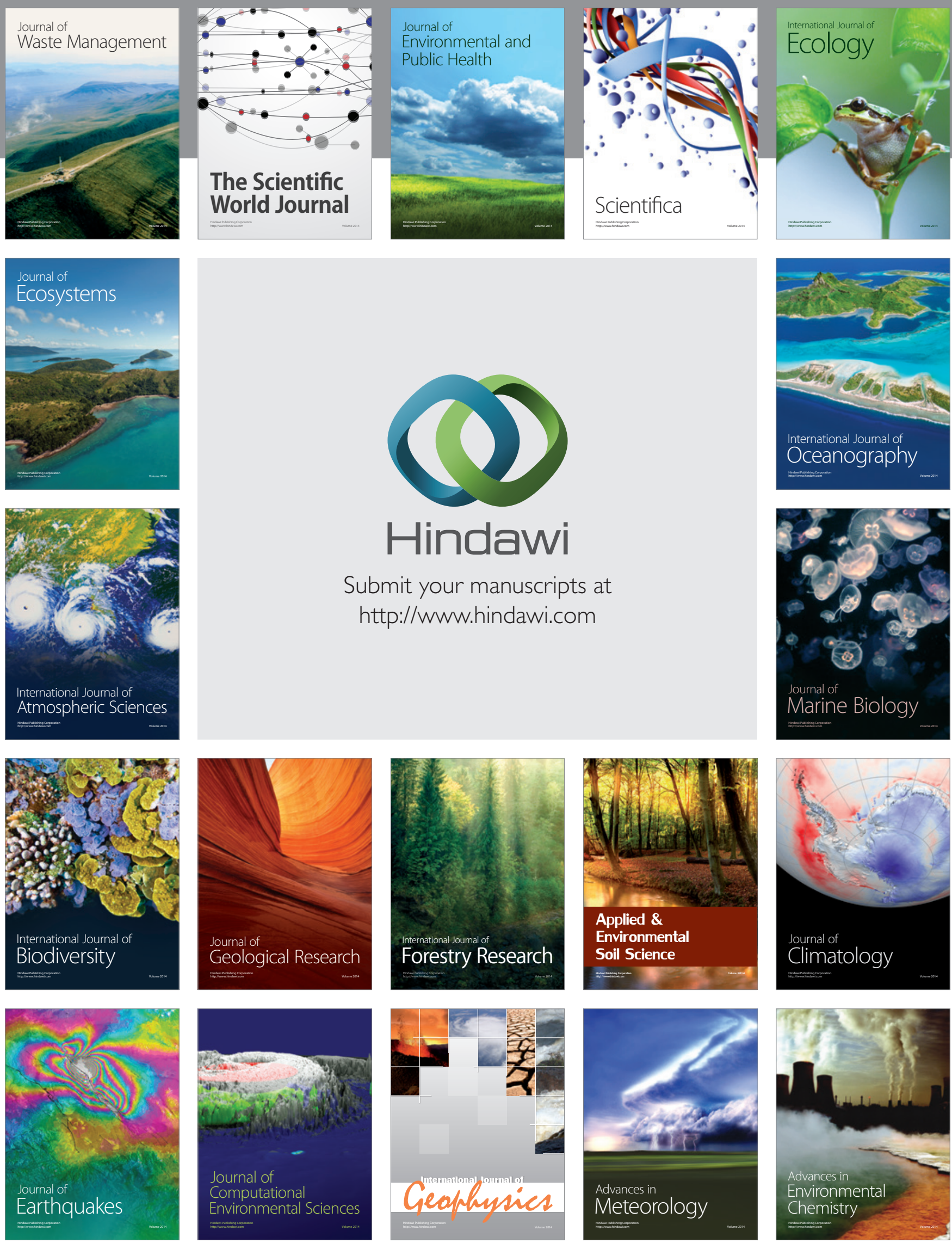